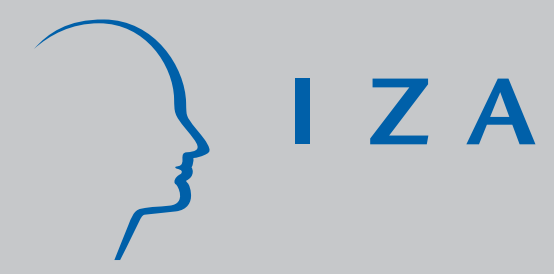

IZADP No. 3931

Cross-Nativity Marriages and Human Capital Levels of Children

Delia Furtado

J anuary 2009 


\title{
Cross-Nativity Marriages and Human Capital Levels of Children
}

\author{
Delia Furtado \\ University of Connecticut \\ and IZA
}

Discussion Paper No. 3931
January 2009

IZA

P.O. Box 7240

53072 Bonn

Germany

Phone: +49-228-3894-0

Fax: +49-228-3894-180

E-mail: iza@iza.org

\begin{abstract}
Any opinions expressed here are those of the author(s) and not those of IZA. Research published in this series may include views on policy, but the institute itself takes no institutional policy positions.

The Institute for the Study of Labor (IZA) in Bonn is a local and virtual international research center and a place of communication between science, politics and business. IZA is an independent nonprofit organization supported by Deutsche Post World Net. The center is associated with the University of Bonn and offers a stimulating research environment through its international network, workshops and conferences, data service, project support, research visits and doctoral program. IZA engages in (i) original and internationally competitive research in all fields of labor economics, (ii) development of policy concepts, and (iii) dissemination of research results and concepts to the interested public.
\end{abstract}

IZA Discussion Papers often represent preliminary work and are circulated to encourage discussion. Citation of such a paper should account for its provisional character. A revised version may be available directly from the author. 


\section{ABSTRACT}

\section{Cross-Nativity Marriages and Human Capital Levels of Children*}

A common perception about immigrant assimilation is that association with natives necessarily speeds the process by which immigrants become indistinguishable from natives. Using 2000 Census data, this paper casts doubt on this presumption by examining the effect of an immigrant's marriage to a native, a measure of social integration, on dropout rates of children from these marriages. Although second-generation immigrants with one native parent generally have lower dropout rates than those with two foreign-born parents, the relationship reverses when steps are taken to control for observable and unobservable background characteristics. That is, immigrants that marry natives have children that are more likely to dropout of high school than immigrants that marry other immigrants. Moreover, gender differences in the effect of marriage to a native disappear in specifications which control for the endogeneity of the marriage decision.

JEL Classification: J12, J61, Z13

Keywords: intermarriage, immigration, education

Corresponding author:

Delia Furtado

Department of Economics

University of Connecticut

341 Mansfield Road

Unit 1063

Storrs, CT 06269-1063

USA

E-mail: Delia.Furtado@uconn.edu

\footnotetext{
* I would especially like to thank Andrew Foster and Stephen Ross for their insightful comments. I am also grateful for the valuable suggestions made by Yoo-Mi Chin, Kenneth Couch, Francesca Fabbri, Rachel Friedberg, Kaivan Munshi, Irina Paley, Almudena Sevilla-Sanz, and Nikos Theodoropoulos as well as seminar and conference participants at the UConn Public Policy Department, IZA's First Migration Topic Week, ESPE 2007, and the UConn-Wesleyan Economics Mini-Conference in 2007. The paper also benefited from the comments of the editors of the volume in which it will appear, two anonymous referees as well as the research assistance provided by Nicholas Jolly. All remaining errors are my own.
} 


\section{Introduction}

Immigration policy has sparked many heated debates in the US, and the question of how fast today's immigrants are assimilating lies at the forefront of this debate. A possible explanation for the lack of consensus is that assimilation, the process by which immigrants and their descendents become indistinguishable from natives, occurs through many different dimensions. Rapid convergence to certain native trends may in fact impede the speed at which immigrants become similar to natives in other aspects. In this paper, I examine the relationship between two different types of assimilation: marital assimilation, or marriage of an immigrant to a native, ${ }^{1}$ and human capital accumulation of children as measured by high school dropout rates.

As discussed in Bean and Stevens (2003), immigration policy has important effects on the marital decisions of immigrants. The 1965 Immigration Reform Act relaxed the quota system in the US, replacing it with a system favoring family reunification. Because spouses are considered immediate family members, marriage to a citizen may have become a particularly attractive method for attaining legal immigrant status. In fact, about 25 percent of immigrants entering the US each year are admitted as spouses of citizens (Bean and Stevens 2003).

Aside from any direct effects on marriage patterns, the law changed the ethnic composition of immigrants making it relatively more difficult for them to find native born spouses of the same race. In contrast to the historically white foreign born population, according to the 2003 Current Population Survey, a little over half of the foreign born today are Latin American and a quarter are Asian (Larsen 2004). Meanwhile, only about 13 percent of the US population is Hispanic and four percent Asian, according to the 2000 Census (Grieco and Cassidy 2001). Qian and Lichter (2001) argue that this change in the racial composition of immigrants decreased the percentage of

\footnotetext{
${ }^{1}$ Throughout the paper, I use cross-nativity marriage and intermarriage synonymously with marriage of an immigrant to a native.
} 
immigrants married to the native born.

The law change is also believed to be responsible for the decline in the relative education levels of immigrants. Although they are just as likely to have a bachelors degree or above, immigrants are much less likely to have a high school diploma and are significantly less likely to have graduated the 9th grade (Larsen 2004). Given the importance of assortative matching on education in the marriage market (see, for example, Furtado 2006), differences in education may also lead to fewer marriages between the foreign born and the native born.

An important question then is whether an immigrant's marriage to another immigrant slows assimilation. Concerned about this very issue, the country of Denmark recently passed legislation which limits the ability of immigrants to import their spouses from their countries of birth. Using this policy change to instrument for immigrants' marriages to other immigrants, Nielson et al. (2007) find that marriage to a native increases the probability that the immigrant is enrolled in school. Employing a different identification strategy, I examine the effect of immigrant-native marriages on high school dropout rates of children from these marriages.

It is particularly important to study outcomes of the second-generation because the native born children of immigrants spend their entire lives in the country. Since they acquire schooling, work, pay taxes, and participate in welfare programs all in the US, their success needs to be carefully considered when calculating the long run costs and benefits of immigration (Card 2005). In this paper, the academic achievement of second-generation immigrants is measured by whether the 16-17 year old children of immigrants have dropped out of school. Although chosen mainly for practical purposes, this is a critical measure of academic success given its impact on later labor market outcomes. High school dropouts, even those who hold a General Educational Development (GED) certificate, have substantially lower earnings than high school graduates (Murnane, Willett, and Tyler 2000). They are also significantly more likely to be unemployed: In 2006, the unemployment 
rate for the general population was 3.6 percent while it was 6.8 percent for high school dropouts (National Center for Educational Statistics 2007).

Studies have shown that the native born, grown children of cross-nativity marriages have better educational outcomes than children of two foreign born parents. After controlling for age, sex, and race, Ramakrishnan (2004) finds that compared to having two foreign born parents, having a native born parent and a foreign born parent decreases the probability of dropping out of high school and increases educational attainment. Similarly, Chiswick and DebBurman (2003) find that children of cross-nativity parents have more years of schooling than children with two foreign born parents.

It is difficult to interpret these findings because it is unclear whether the positive effects of having a native born parent are coming from individual characteristics of the immigrant parent that chooses to marry a native, characteristics of the native born parent that chooses to marry an immigrant, or attributes of the marriages themselves including the communities surrounding these marriages. Using 2000 Census data, this paper presents preliminary evidence consistent with the findings of Ramakrishnan (2004) and Chiswick and DebBurman (2003) that second-generation immigrants with a native born parent perform better than those with two foreign born parents. However, after controlling for even the most basic parental background variables such as education and income, the relationship reverses. In order to control for the endogeneity of the marriage decision, this paper takes the approach common in the intermarriage literature which is to exploit information on the availability of foreign born potential spouses in one's marriage market. Ordinary least squares estimates with a full set of controls and instrumental variable estimates both suggest that an immigrant's marriage to a native as opposed to another immigrant results in higher dropout rates for children from these marriages.

This study also investigates whether the effects of an immigrant's marriage to a native differs by gender. Least squares regressions which control for a variety of family characteristics suggest 
that a foreign born female's marriage to a native has no significant impact on her child's probability of dropping out while a foreign born male's marriage to a native increases the probability that his child drops out. However, in IV specifications, there are no significant differences in the effects of marriage to a native by gender: For both immigrant males and females, marriage to a native increases the probability that a child drops out of high school by about 10 percentage points. ${ }^{2}$

The remainder of the paper is organized as follows. In Section 2, I discuss the theoretical underpinnings of the analysis. Section 3 describes the data and presents preliminary descriptive analyses. Section 4 provides an empirical strategy for identifying the causal impact of intermarriage on children's dropout rates and discusses results. Gender differences in the effects of marriage to a native are also explored in this section. Section 5 concludes with a discussion of the significance of the findings.

\section{Theoretical Background and Empirical Approach}

There are two main types of causal mechanisms through which an immigrant's marriage to another immigrant could affect child outcomes. First, even if marriage partners are randomly assigned, parents born in the same country may have a different technology for producing child human capital and this could lead to either positive or negative outcomes for their children. For example, the second-generation immigrants with a native born parent are more likely to have English as a first language and even only language (Stevens and Swicegood 1985) when compared to children with two foreign born parents. Since English proficiency is positively correlated with academic outcomes even after controlling for a number of household characteristics (Glick and White 2003,

\footnotetext{
${ }^{2}$ In a study exploiting the plausibly random allocation of Moluccan immigrants across the Netherlands, van Ours and Veenman (2008) find that children from marriages with a Moluccan father and a native mother have a higher educational attainment than children from ethnic homogeneous Moluccan couples and children from a Moluccan mother and a native father. Our results suggest that immigrants in the US do not seem to assimilate via the same processes as Moluccans in the Netherlands.
} 
Portes and Rumbaut 2001, Bleakley and Chin 2008), having a native born parent could lead to positive outcomes for children. On the other hand, children with two foreign born parents are more likely to be bilingual and this has also been found to have a positive effect on achievement (Portes and Rumbaut 2001). Immigrant parents have also been thought to be more optimistic about their children's futures than native born parents (Kao and Tienda 1995). If immigrant parents have higher aspirations for their children than native parents, then same-nativity marriages may positively influence the probability that children of immigrants finish high school. Moreover, when both parents are born abroad, their similar convictions concerning child-rearing may improve their parenting efficiency.

Another mechanism through which marriage could affect child outcomes is related to ethnic connections outside of the household. Immigrant-immigrant marriages are likely to result in more ethnic connections than immigrant-native marriages. Theoretically, a strong attachment to an ethnic community has an ambiguous effect on socioeconomic outcomes of children. Immigrants involved in their ethnic communities may be more likely to share information regarding the best schools and how education decisions translate to job opportunities in the US. On the other hand, if participation in an ethnic network comes at the expense of association with natives, then immigrants may forego on spillovers from natives' better educational outcomes.

Foreign born couples differ from mixed couples in many characteristics which may affect their children's educational outcomes making it difficult to identify the causal effect of marriage type. Perhaps most importantly, they have different levels of education. Parental skill levels are not the only inputs into child education production functions. A series of studies have found that immigrants married to natives have higher earnings than immigrants married to other immigrants (Meng and Gregory 2005, Kantarevic 2004, Meng and Meurs 2006). ${ }^{3}$ If these higher earnings are

\footnotetext{
${ }^{3}$ Although Meng and Gregory (2005) and Meng and Meurs (2006) suggest that intermarriage has a causal effect
} 
used to finance better schools, tutoring services, and other educational resources, then this could explain why children with two foreign born parents have worse educational outcomes than children with one native born parent. Also, the classic quantity/quality trade-off in children suggests that families with more children cannot afford to invest as much in their human capital. If immigrants that choose to marry other immigrants have a higher relative preference for quantity of children as opposed to quality or alternatively, face a higher relative price for quality of children, they will choose to have more children but invest less in their human capital (see Chiswick 1988). There is also evidence that the labor supply of female immigrants differs depending on whether they are married to immigrants or natives (Baker and Benjamin 1997). ${ }^{4}$ Although the literature has not produced a conclusive answer as to how mother's labor supply affects child outcomes, it is important to take it into account. The present study controls for all of these avenues which could be generating a spurious correlation between intermarriage and child outcomes.

It is also necessary to consider the locations where the immigrants that are most likely to marry other immigrants live. The foreign born that reside within close geographic proximity to other immigrants are less likely to marry natives, but are more likely to benefit from ethnic networks. There is a large literature on the benefits of ethnic networks for finding jobs (Edin et al. 2003, Munshi 2003), and these same networks could benefit children's educational attainment. Moreover, studies have shown that attachment to an ethnic network is more useful when the network is larger (Gang and Zimmerman 2000). To account for these issues, the empirical analysis in this paper controls for both the size of the immigrant population in the immigrant's state as well as whether or not the immigrant lives in a metropolitan area. Also, because there is substantial regional variation

on immigrant's earnings in Australia and France respectively, Kantarevic (2004) fails to find a causal effect for immigrants in the US.

${ }^{4}$ Baker and Benjamin (1997) conclude that family composition is an important correlate of assimilation for immigrants in Canada. They present evidence consistent with the family investment model, which predicts that foreign born women accept dead-end jobs in order to provide liquidity for their immigrant husbands' investment in human capital. Blau et al. (2003) find no such evidence for the US. 
in both educational outcomes and the size of the immigrant population, region of residence is also controlled for in the empirical analysis.

There is tremendous variation in average educational attainment by ethnic group. In fact, 30 percent of the variation in the education of immigrants can be explained simply with country of origin dummy variables (Card 2005). Certain ethnic groups, for many reasons, may invest less in their children's education and have low intermarriage rates. For example, foreign born males in ethnic groups with strict gender roles may find it more difficult to find native women accepting of traditional gender roles and may also place less value on children's education. As another example, immigrants in groups with a long history of migration to the US may find it easier to find natives with similar values. If these groups have unusually high or low levels of education, then the estimate of the effect of marriage to a native will be significantly biased. To deal with these concerns, country of birth fixed effects are accounted for in the analysis.

Because even within ethnic groups and controlling for a relatively extensive list of observable characteristics, immigrants that choose to marry other immigrants may be different from immigrants that choose to marry natives, endogeneity bias remains a concern. To address endogeneity issues, an instrumental variables approach is taken in this paper. Since one's spouse choice and decisions regarding child raising are very much intertwined, it is difficult to find a variable correlated with whether or not one's spouse is foreign born but excluded from a child outcome equation. Meng and Gregory (2005) deal with this problem by instrumenting for the intermarriage decision using ethnic group size and sex-ratios within ethnicity-age-religion cells. Building on this technique, I instrument for marriage decisions of foreign born males (females) using the size of the foreign born never-married female (male) population of a similar age when and where immigrants were most likely searching for spouses. 


\section{Data Description}

The main analysis in this paper utilizes data from the 5\% Public Use Samples of the 2000 US Census on families with at least one foreign born parent, while the excluded instrumental variable is constructed using the $5 \%$ sample of the 1980 US Census. Both sets of data were obtained from the Integrated Public Use Microdata Series (IPUMS) (Ruggles 2003). These samples contain detailed information on household and person level characteristics yet are large enough to construct accurate measures of the size of foreign born population in relatively narrow gender-age-state cells. A major disadvantage of these data is that parental information on issues such as country of birth and years of schooling, is only available for children residing with both parents. ${ }^{5}$ For this reason, only the outcomes of native born children who are between the ages of 16 and 17 and residing with both biological parents are considered in the analysis. In families with more than one child in this age range, only the eldest is used. Because it is important to control for earnings when examining the effect of marital decisions on child outcomes, families in which both mothers and fathers have zero earnings are dropped from the sample. Lastly, we consider only the effects of marital decisions of immigrants between the ages of 35 and 64 that are either household heads or their spouses.

Because adult children living with both parents may be a very selected sample, the outcome of interest used in the analysis is whether a child, aged 16 or 17, is still enrolled in school. Since the structure of the US economy has shifted towards skill-intensive jobs, high school dropouts face particularly strong barriers to economic progress. Thus, even if immigrant intermarriage decisions have only a small effect on high school dropout rates of their children, this can imply substantial differences in intergenerational assimilation patterns.

The independent variable of interest is whether an immigrant is married to a native, or from

\footnotetext{
${ }^{5}$ Information on country of birth for parents is asked of all respondents in the Current Population Survey (CPS) starting in 1994. However, other parental variables important for this study-such as education, income levels, age, and years in the US-are not available.
} 
a different perspective, whether the 16-17 year old child has one as opposed to two foreign born parents. It is important to keep in mind that when two immigrants marry each other, they need not have the same country of birth. For example, a Mexican-born immigrant married to a German immigrant is classified as belonging to an immigrant-immigrant marriage in this study. Meanwhile, a Mexican immigrant marrying a second-generation Mexican immigrant is classified as marrying a native. The first issue proves not to be much of a concern, since 92 percent of all of the marriages between two immigrants in the sample involve immigrants with the same country of birth. Moreover, most of the eight percent from different countries are from countries with the same cultural background, such as a Mexican marrying someone from Central America (Author's own calculations).

Because parents' countries of birth was not asked in the 2000 Census, it is difficult to measure the extent to which immigrants marrying natives are marrying the native born children of immigrants from the same country of birth. The Census does contain information on ancestry, but responses to the ancestry question have been found to be inconsistent (Farley 1991). ${ }^{6}$ According to the 1970 Census, the last Census to ask for parents' countries of birth, of the immigrants that marry natives, only about ten percent marry children of immigrants from their country of birth (Furtado 2006). ${ }^{7}$

Table 1 presents descriptive statistics for the sample used in the analysis. A little over 40 percent of all marriages comprised of at least one foreign born spouse, involve one native born spouse. Table 1 also compares child dropout rates by marriage types of parents. ${ }^{8}$ Teenagers with a

\footnotetext{
${ }^{6}$ Farley (1991) carefully documents the problems with the ancestry question. Many respondents leave the question blank and it is unclear whether they are puzzled by the question or do not identify with a particular ancestry. For those that do answer the question, responses are very inconsistent. Farley writes that possible explanations for these inconsistencies include ethnic intermarriage, the many generations that may separate the respondents from their foreign born descendents, and "the apparent unimportance of ancestry to many whites of European origin."

${ }^{7}$ Because composition of immigrants has changed quite a bit since the 1970 Census, it is unclear whether these patterns remain in the year 2000. However, even if all immigrants marrying natives were marrying second-generation immigrants with same country of origin, these native born spouses would still be more assimilated than foreign born spouses and so the conclusions of the paper regarding the assimilation process of immigrants would remain the same.

${ }^{8}$ These dropout rates are significantly lower than in the general population because of the restrictions that children are between the ages of 16 and 17 and must be living with both biological parents. Duncan and Trejo (2008)
} 


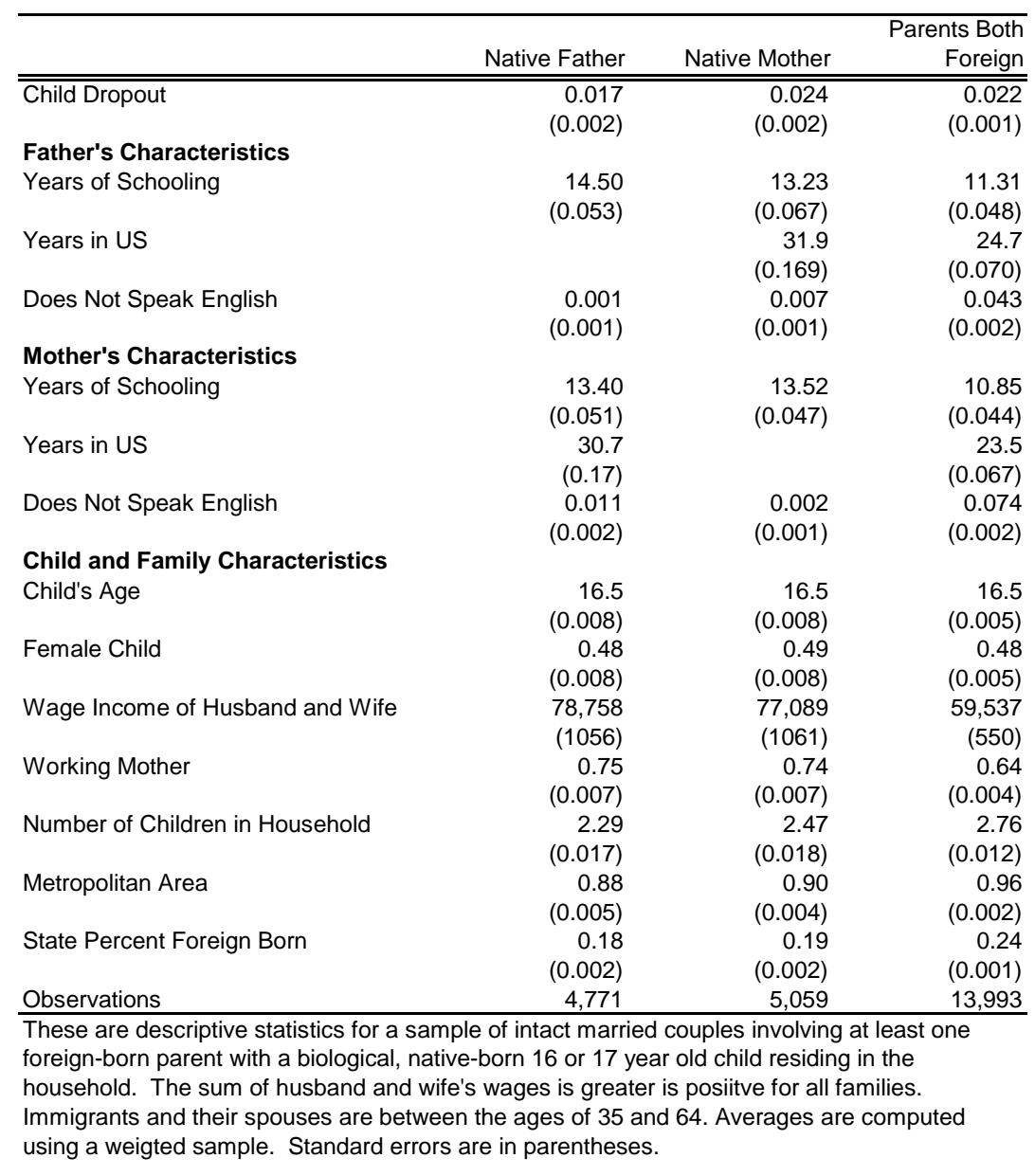

Table 1: Descriptive Statistics by Marriage Type

US born mother and foreign born father have the highest dropout rates (2.4 percent) and children with a US born father and a foreign born mother have the lowest dropout rates (1.7 percent).

As discussed in the previous section, there are many parental characteristics which may affect both intermarriage rates and dropout rates of children. The foreign born have fewer years of schooling than the native born. ${ }^{9}$ Consistent with the literature on assortative mating on education, immigrants that marry other immigrants have fewer years of schooling than those that marry

and Bleakley and Chin (2008) find similar dropout rates using a similar sample. Also, The National Education Longitudinal Study of 1988 (NELS:88) has data on whether parents are native or foreign born regardless of coresidence. Based on the author's calculations, the relationships between 8th grade grades and family type using NELS:88 data closely mirror the relationships for dropout rates by family type using Census data.

${ }^{9}$ The 2000 Census contains information on educational attainment. To construct a continuous years of schooling variable from last grade completed and degree achieved, I used the mapping in Kalmijn (1996). 
natives. The native born males married to foreign born females have the highest levels of education. Income patterns mirror education patterns, with households composed of two immigrant parents having significantly less income than any of the other categories. Families with two foreign born parents have more children than families with a native parent. Similarly, mothers are more likely be in the labor force if they are married to a native. Not surprisingly, the foreign born married to the foreign born have lived in the US for fewer years and are less likely to speak English than those married to natives. They are also more likely to live in metropolitan areas and in states with large immigrant populations.

\section{Analytical Strategy and Results}

\subsection{Least Squares Specification}

The purpose of this study is to disentangle the effects of marriage to a native on children's academic outcomes from the characteristics of the immigrants and the natives that choose to intermarry. Consider the following equation for estimating the probability that an immigrant's teenager is a high school dropout, where $i$ denotes the immigrant and $j$ the country of birth:

$$
D_{i j}=\alpha_{1} N B_{i j}^{S}+\alpha_{2} X_{i j}+\alpha_{3} X_{i j}^{S}+\alpha_{4} X_{i j}^{C}+\gamma_{j}+\varepsilon_{i j}
$$

$D$ is a dichotomous variable taking the value of one if the immigrant's teenager is not enrolled in school and does not have a high school degree and zero otherwise, $N B^{S}$ is a dichotomous variable equal to one if the immigrant's spouse is native born and zero if he/she is foreign born, $X$ is a vector of the immigrant's characteristics such as education, language ability, and years in the

US, $X^{S}$ is a vector of the spouse's characteristics, and $X^{C}$ is a vector of child or neighborhood characteristics such as child age and whether the family lives in a metropolitan area. Since there 
are many unobserved factors associated with an immigrant's country of origin that influence both propensity to marry a native and educational outcomes of children, $\gamma$, a vector of country of origin fixed effects, is included in the specification. Any unobserved heterogeneity will be captured in $\varepsilon$.

The construction of these variables is simple for couples consisting of an immigrant and a native since the immigrant is the person of interest and the native is the spouse. For immigrant-immigrant couples, however, this classification is not straightforward. For the analysis shown, I classify the immigrant that has been in the US for the least amount of time as the person of interest. Thus, for all couples, the effects of marriage decisions of the least assimilated spouse are considered. For immigrant-immigrant couples where both spouses arrive in the same year, I define the husband to be the person of interest, but results do not change when I let the wife be the person of interest and her husband the spouse. ${ }^{10}$

Table 2 presents the coefficients of equation 1 estimated using a linear probability model. Column 1 shows the effect of a native born parent on the probability of dropping out when controlling for only a baseline set of variables. Consistent with Ramakrishnan (2004) and Chiswick and DebBurman (2003), marriage to a native is generally associated with a decrease in children's dropout tendencies. As discussed in the previous section, interpretation of this result is difficult because mixed families have characteristics which may affect child outcomes for reasons unrelated to country of birth of parents. For example, Table 1 shows that parents in mixed marriages have more years of schooling, better language skills, and higher earnings, all of which are associated with lower child dropout rates. In column 2, controls for own and spouse years of schooling as well as income, whether the mother works outside of the home, and number of children in the household are added.

\footnotetext{
${ }^{10}$ To check robustness, I ran specifications which classified the person of interest as the immigrant that has been in the US longer. I also conducted the analysis only on foreign born household heads, defining the spouse to be the spouse of the head. Lastly, I randomly assigned the husband to be the person of interest and the wife to be the spouse for half of the couples. For the other half, I assign the wife to be the person of interest and the husband to be the spouse. For all methods of identifying the person of interest, the main results were robust.
} 
The coefficient on marriage to a native reverses in sign and remains statistically significant suggesting that the lower dropout rates of children with a native born parent can be entirely explained by characteristics of parents that choose to intermarry. In fact, controlling for the education variables alone is sufficient to generate a positive relationship between marriage to a native and children's probability of dropping out of high school.

Column 3 adds to the model measures of immigrant assimilation, specifically whether both spouses speak English, size of the immigrant population in the immigrant's state of residence, and maximum years since migration. Years since migration is set to zero for natives. When both spouses are foreign born, the variable takes the value of the spouse that has been in the U.S. for the most time. The coefficient on native born parent increases further when these variables are added to the model. Lastly, column 4 incorporates country of birth fixed effects. Although the coefficient on marriage to a native is no longer significant at the 10 percent value (p-value of .11), the magnitude of the coefficient remains similar to the other specifications. In specifications which control for parental characteristics, the least squares estimates suggest that an immigrant's marriage to a native increases his or her child's probability of dropping out by half or a little less than a half a percentage point.

\subsection{An Instrumental Variables Approach}

Further difficulty in this type of analysis arises from the unobserved characteristics of the immigrants that choose to marry natives and the natives that choose to marry immigrants. In equation 1 , the unobserved characteristics in $\varepsilon$ could potentially be correlated with $N B$ and thus lead to biased estimates of $\alpha_{1}$. From a theoretical perspective, the bias cannot be signed. On the one hand, 


\begin{tabular}{|c|c|c|c|c|}
\hline Child Dropout & 1 & 2 & 3 & 4 \\
\hline Native Spouse & $\begin{array}{l}-0.004^{*} \\
(0.002)\end{array}$ & $\begin{array}{l}0.004^{*} \\
(0.002)\end{array}$ & $\begin{array}{l}0.005^{\star *} \\
(0.002)\end{array}$ & $\begin{array}{l}0.004 \\
(0.003)\end{array}$ \\
\hline Child's Age & $\begin{array}{l}0.007^{\star * *} \\
(0.002)\end{array}$ & $\begin{array}{l}0.007^{* * *} \\
(0.002)\end{array}$ & $\begin{array}{l}0.007^{* * *} \\
(0.002)\end{array}$ & $\begin{array}{l}0.007^{* * *} \\
(0.002)\end{array}$ \\
\hline Female Child & $\begin{array}{l}-0.008^{* * *} \\
(0.002)\end{array}$ & $\begin{array}{l}-0.008^{\star * *} \\
(0.002)\end{array}$ & $\begin{array}{l}-0.008^{\star * \star} \\
(0.002)\end{array}$ & $\begin{array}{l}-0.008^{* * *} \\
(0.002)\end{array}$ \\
\hline Metropolitan Area & $\begin{array}{l}-0.000 \\
(0.005)\end{array}$ & $\begin{array}{l}0.003 \\
(0.005)\end{array}$ & $\begin{array}{l}0.003 \\
(0.005)\end{array}$ & $\begin{array}{l}0.004 \\
(0.005)\end{array}$ \\
\hline Years of Schooling & & $\begin{array}{l}-0.001^{* * *} \\
(0.000)\end{array}$ & $\begin{array}{l}-0.001^{* * *} \\
(0.000)\end{array}$ & $\begin{array}{l}-0.001^{* \star *} \\
(0.000)\end{array}$ \\
\hline Spouse Years of Schooling & & $\begin{array}{l}-0.001^{\star \star *} \\
(0.000)\end{array}$ & $\begin{array}{l}-0.001^{* * *} \\
(0.000)\end{array}$ & $\begin{array}{l}-0.001^{* * *} \\
(0.000)\end{array}$ \\
\hline Log Couple's Wage Income & & $\begin{array}{l}-0.002 \\
(0.001)\end{array}$ & $\begin{array}{l}-0.001 \\
(0.001)\end{array}$ & $\begin{array}{l}-0.001 \\
(0.001)\end{array}$ \\
\hline Working Mother & & $\begin{array}{l}0.001 \\
(0.002)\end{array}$ & $\begin{array}{l}0.001 \\
(0.003)\end{array}$ & $\begin{array}{l}0.001 \\
(0.003)\end{array}$ \\
\hline Number of Children in Household & & $\begin{array}{l}0.002^{* *} \\
(0.001)\end{array}$ & $\begin{array}{l}0.002^{*} \\
(0.001)\end{array}$ & $\begin{array}{l}0.002^{*} \\
(0.001)\end{array}$ \\
\hline Maximum Years in US & & & $\begin{array}{l}-0.000^{*} \\
(0.000)\end{array}$ & $\begin{array}{l}-0.000^{*} \\
(0.000)\end{array}$ \\
\hline Does Not Speak English & & & $\begin{array}{l}0.035^{\star * *} \\
(0.012)\end{array}$ & $\begin{array}{l}0.034^{* * *} \\
(0.012)\end{array}$ \\
\hline Spouse Does Not Speak English & & & $\begin{array}{l}0.003 \\
(0.008)\end{array}$ & $\begin{array}{l}0.001 \\
(0.008)\end{array}$ \\
\hline State Percent Foreign Born & & & & $\begin{array}{l}-0.030 \\
(0.019)\end{array}$ \\
\hline Region Dummies & Yes & Yes & Yes & Yes \\
\hline Country of Birth Dummies & No & No & No & Yes \\
\hline Constant & $\begin{array}{l}-0.088^{* *} \\
(0.034)\end{array}$ & $\begin{array}{l}-0.039 \\
(0.036)\end{array}$ & $\begin{array}{l}-0.047 \\
(0.036)\end{array}$ & $\begin{array}{l}-0.042 \\
(0.039)\end{array}$ \\
\hline Observations & 23823 & 23823 & 23823 & 23823 \\
\hline \multicolumn{5}{|c|}{$\begin{array}{l}\text { This table reports regression coefficients from least squares models. The } \\
\text { sample consists of intact married couples involving at least one foreign-born } \\
\text { parent with a biological, native-born } 16 \text { or } 17 \text { year old child residing in the } \\
\text { household. The sum of husband and wife's wages is greater is posiitve for all } \\
\text { families. Immigrants and their spouses are between the ages of } 35 \text { and } 64 \text {. } \\
p<0.01,{ }^{* *} p<0.05,{ }^{*} p<0.10 \text {. }\end{array}$} \\
\hline
\end{tabular}

Table 2: Ordinary Least Squares and Fixed Effects Estimates 
higher ability immigrants may be both more likely to marry natives and have higher ability children, regardless of whom they marry. This would lead to a negative bias on $\alpha_{1}$, meaning least squares estimates would suggest that native born parents decrease dropout rates of children more than they actually do. On the other hand, if immigrants prefer to marry natives, for example because natives can give them citizenship status, then at equilibrium, the unobserved characteristics of the natives that immigrants marry be worse than the unobserved characteristics of the immigrants that immigrants marry. ${ }^{11}$ Moreover, if immigrants that choose to marry other immigrants are more optimistic about their children's success, then children with two immigrant parents may have higher academic aspirations than children with only one immigrant parent. This would also lead to a positive bias on $\alpha_{1}$. That is, least squares estimates would imply that native born parents increase dropout rates more than they actually do.

To deal with these issues, an IV approach is taken. The excluded instrument used is the percent foreign born of the never married population of the opposite sex within the immigrant's desired age group in the state in which he or she was most probably searching for a spouse. Age groups are established using five year intervals and males are assumed to search for females two years younger than them. ${ }^{12}$ Also, when the state of current residence is different from the state of birth of the immigrant's teenager, immigrants are assumed to have been searching for a spouse in the state of birth of the child. Theory suggests that the larger the share of foreign born potential spouses, the less likely it is that an immigrant marries a native even just by random matching. ${ }^{13}$

\footnotetext{
${ }^{11}$ This is a special case of Merton's exchange hypothesis (1941). Celikaksoy et al. (2006) find that Pakistani marriage migrants to Denmark have higher education levels than the Danes that marry Pakistani immigrants. This suggests that Pakistani marriage migrants are willing to pay a premium in order to live in Denmark. However, Turkish marriage migrants have lower education levels than the Danes that marry Turks suggesting that Turkish immigrants are willing to pay a premium for the "unspoiled traditional norms" possessed by potential spouses in their home countries.

${ }^{12}$ Six age groups are established for the immigrants in the analysis: 35-39, 40-44, 45-49, 50-54, 55-59, and 60-64. Since spouses of males are typically two years younger than their husbands, the corresponding age groups for females in the year 2000 are 33-37, 38-42, 43-47, 48-52, 53-57, and 58-62 but because we count their numbers in the year 1980, the corresponding age groups for women are 13-17, 18-22, 23-27, etc. For females, the relevant age groups in 1980 are $17-21,22-26,27-31$, etc.

${ }^{13}$ I also tried to use the sex-ratio within each ethnic group as an instrument for whether the spouse of an immigrant
} 
There are several reasons one may be concerned about the validity of this instrumental variable. Low-skilled immigrants may tend to reside in states with more favorable local labor markets for unskilled labor. These states would then be likely to have large foreign born populations and high dropout rates. Alternatively, if ambitious immigrants migrate to states with better opportunities for their educated children as opposed to themselves, then there would be bias on the intermarriage coefficient in the opposite direction. To mitigate these concerns, this paper exploits the fact that parents make marriage choices and children make educational decisions at different times and often, different places. Thus, the specification allows the state size of the foreign born population in the year 2000 to affect whether or not the child remains in school in the year 2000. The identifying restriction then becomes that conditional on the size of the foreign born population in a state in the year 2000, the size of the never-married foreign born population of the opposite sex in the immigrant's age group in 1980 in the state of birth of the child only affects an immigrant's child's probability of dropping out through the nativity of the immigrant's spouse.

To be more precise, the following equations are estimated in an instrumental variables framework:

$$
\begin{aligned}
D_{i j a s}^{2000} & =\beta_{1} N B_{i j a s}^{2000}+\beta_{2} X_{i j a s}^{2000}+\beta_{3} X_{i j a s}^{s, 2000}+\beta_{4} P_{s}^{2000}+\gamma_{j}+\varepsilon_{i j a s} \\
N B_{i j a s}^{2000} & =\theta_{1} P_{a s^{\prime}}^{1980}+\theta_{2} X_{i j a s}^{2000}+\theta_{3} X_{i j a s}^{s, 2000}+\theta_{4} P_{s}^{2000}+\tau_{j}+u_{i j a s}
\end{aligned}
$$

where $P_{a s^{\prime}}^{1980}$ denotes the 1980 proportion foreign born of the never married opposite-sex population in the immigrant's age group, $a$, in the state where he or she lived approximately twenty years prior to the survey, sl. Again, I use the state of birth of the 16 or 17 year old child to determine where the immigrant was living in 1980. Also, recall that the sample consists of families with at least one is foreign born. The instrument proved to be too weak for this analysis. 
foreign born spouse. For immigrant-immigrant couples, the immigrant that has been in the US for the least amount of time is considered the person of interest and the analysis examines the effect of the nativity of his or her spouse.

The first column of Table 3 presents first stage coefficients for equation system $2 . \quad$ Results suggest that a 1 percentage point increase in the proportion foreign born of the opposite sex in a state in 1980 leads to a 0.73 percentage point decrease in the probability that an immigrant is married to a native in the year 2000. This effect is significant at the one percent level. The first stage F and Cragg-Donald statistics on all specifications are far above the conventional cut-off points for weak instruments.

Column 2 of table 3 presents second stage results from the instrumented regressions. Compared to the least squares estimates, the coefficient on native born spouse increases in magnitude suggesting that it is the foreign born that are mostly likely to have dropout children that marry immigrants. After correcting for this selection, it is even more beneficial for children's educational outcomes for immigrants to marry other immigrants. ${ }^{14}$

Part of the identification arises from cross-state variation in the size of the foreign born population. There could, however, be other factors correlated with the size of the foreign born population which vary by state. For example, perhaps immigrants tend to live in states with better education policies. For this reason, average years of schooling, computed using all adults aged 25 and above, by state is included in the empirical specification shown in column 3 . The coefficient on native born spouse is not affected suggesting that state differences in education are not driving the results.

\footnotetext{
${ }^{14}$ Because IV strategies only recover local average treatment effects (LATE), it is important to consider which immigrants would be most affected by the instrument. One can imagine that if marriage decisions were at least partly determined by random matching (see Furtado 2006 for a simple model of interethnic marriage incorporating random matching), the marriage decisions of all foreign born males are affected by an increase in the percentage of foreign born potential spouses. However, certain immigrants should be more sensitive to the availability of foreign born spouses than others. For example, some immigrants will marry immigrants, perhaps by importing a spouse, regardless of how difficult it is to find an immigrant spouse. This could be due to language barriers or their "unattractiveness" to natives. These immigrants would not be affected by the IV and so the results in this paper do not apply to this group.
} 


\begin{tabular}{|c|c|c|c|c|c|}
\hline & $\begin{array}{l}\text { First Stage: } \\
\text { Native } \\
\text { Spouse } \\
\end{array}$ & \multicolumn{4}{|c|}{ Second Stage: Child Dropout } \\
\hline & & & & $\begin{array}{c}\text { Different } \\
\text { Spouse } \\
\text { Arrival } \\
\text { Year }\end{array}$ & $\begin{array}{l}\text { Arrive } \\
\text { Before } \\
\text { Age } 18\end{array}$ \\
\hline & 1 & 2 & 3 & 4 & 5 \\
\hline $\begin{array}{l}\text { Percent Foreign Opposite Sex } \\
\text { in State and Age Group } 1980\end{array}$ & $\begin{array}{r}-0.727^{\star \star *} \\
(0.133)\end{array}$ & & & & \\
\hline Native Spouse & & $\begin{array}{r}0.130^{\star * *} \\
(0.041)\end{array}$ & $\begin{array}{r}0.125^{\star \star *} \\
(0.040)\end{array}$ & $\begin{array}{r}0.116^{\star \star *} \\
(0.035)\end{array}$ & $\begin{array}{r}0.110^{* * \star} \\
(0.042)\end{array}$ \\
\hline Child's Age & $\begin{array}{r}-0.011^{* *} \\
(0.004)\end{array}$ & $\begin{array}{r}0.009^{* * *} \\
(0.002)\end{array}$ & $\begin{array}{r}0.009^{* * *} \\
(0.002)\end{array}$ & $\begin{array}{r}0.011^{\star * *} \\
(0.002)\end{array}$ & $\begin{array}{l}0.007^{* \star} \\
(0.003)\end{array}$ \\
\hline Female Child & $\begin{array}{r}0.005 \\
(0.006)\end{array}$ & $\begin{array}{r}-0.009^{\star * \star} \\
(0.002)\end{array}$ & $\begin{array}{r}-0.008^{\star * \star} \\
(0.002)\end{array}$ & $\begin{array}{r}-0.010^{\star * \star} \\
(0.002)\end{array}$ & $\begin{array}{r}-0.011^{\star \star \star} \\
(0.003)\end{array}$ \\
\hline Metropolitan Area & $\begin{array}{r}-0.104^{* * *} \\
(0.014)\end{array}$ & $\begin{array}{l}0.017^{\star *} \\
(0.007)\end{array}$ & $\begin{array}{l}0.016^{\star *} \\
(0.007)\end{array}$ & $\begin{array}{l}0.015^{\star \star} \\
(0.007)\end{array}$ & $\begin{array}{r}0.012 \\
(0.009)\end{array}$ \\
\hline Years of Schooling & $\begin{array}{r}-0.005^{\star \star \star} \\
(0.001)\end{array}$ & $\begin{array}{l}-0.001 \\
(0.000)\end{array}$ & $\begin{array}{l}-0.001 \\
(0.000)\end{array}$ & $\begin{array}{r}-0.001^{\star *} \\
(0.000)\end{array}$ & $\begin{array}{r}-0.002^{\star \star} \\
(0.001)\end{array}$ \\
\hline Spouse Years of Schooling & $\begin{array}{r}0.026^{\star \star *} \\
(0.001)\end{array}$ & $\begin{array}{r}-0.005^{\star \star \star} \\
(0.001)\end{array}$ & $\begin{array}{r}-0.004^{\star \star \star} \\
(0.001)\end{array}$ & $\begin{array}{r}-0.005^{\star * *} \\
(0.001)\end{array}$ & $\begin{array}{r}-0.004^{\star \star \star} \\
(0.001)\end{array}$ \\
\hline Log Couple's Wage Income & $\begin{array}{r}0.011^{* * *} \\
(0.004)\end{array}$ & $\begin{array}{l}-0.003^{*} \\
(0.002)\end{array}$ & $\begin{array}{l}-0.003^{*} \\
(0.002)\end{array}$ & $\begin{array}{r}-0.004^{\star *} \\
(0.002)\end{array}$ & $\begin{array}{r}-0.007^{\star \star \star} \\
(0.002)\end{array}$ \\
\hline Working Mother & $\begin{array}{r}0.035^{\star \star *} \\
(0.006)\end{array}$ & $\begin{array}{r}-0.003 \\
(0.003)\end{array}$ & $\begin{array}{r}-0.003 \\
(0.003)\end{array}$ & $\begin{array}{r}-0.004 \\
(0.003)\end{array}$ & $\begin{array}{r}-0.005 \\
(0.004)\end{array}$ \\
\hline Number of Children in Household & $\begin{array}{r}-0.011^{\star \star \star} \\
(0.003)\end{array}$ & $\begin{array}{r}0.003^{\star \star \star} \\
(0.001)\end{array}$ & $\begin{array}{r}0.003^{\star \star \star} \\
(0.001)\end{array}$ & $\begin{array}{l}0.003^{* *} \\
(0.001)\end{array}$ & $\begin{aligned} 0.003^{*} \\
(0.002)\end{aligned}$ \\
\hline Maximum Years in US & $\begin{array}{r}0.003^{\star \star *} \\
(0.000)\end{array}$ & $\begin{array}{r}-0.001^{\star \star *} \\
(0.000)\end{array}$ & $\begin{array}{r}-0.001^{\star \star *} \\
(0.000)\end{array}$ & $\begin{array}{l}-0.000 \\
(0.000)\end{array}$ & $\begin{array}{r}-0.001^{* \star \star} \\
(0.000)\end{array}$ \\
\hline Does Not Speak English & $\begin{array}{l}-0.001 \\
(0.013)\end{array}$ & $\begin{array}{l}0.035^{\star \star} \\
(0.015)\end{array}$ & $\begin{array}{l}0.035^{\star *} \\
(0.015)\end{array}$ & $\begin{array}{l}0.041^{* *} \\
(0.017)\end{array}$ & $\begin{array}{r}0.012 \\
(0.012)\end{array}$ \\
\hline Spouse Does Not Speak English & $\begin{array}{r}-0.161^{* \star \star} \\
(0.023)\end{array}$ & $\begin{array}{l}0.022^{\star *} \\
(0.011)\end{array}$ & $\begin{array}{l}0.021^{* *} \\
(0.010)\end{array}$ & $\begin{array}{l}0.024^{* *} \\
(0.012)\end{array}$ & $\begin{array}{r}0.013 \\
(0.015)\end{array}$ \\
\hline State Percent Foreign Born & $\begin{array}{r}-0.531^{* * \star} \\
(0.074)\end{array}$ & $\begin{array}{l}0.069^{* *} \\
(0.033)\end{array}$ & $\begin{array}{l}0.090^{* *} \\
(0.036)\end{array}$ & $\begin{array}{l}0.071^{\star *} \\
(0.033)\end{array}$ & $\begin{array}{r}0.040 \\
(0.037)\end{array}$ \\
\hline $\begin{array}{l}\text { Average Years of Schooling in } \\
\text { State }\end{array}$ & & & $\begin{array}{l}0.016^{\star *} \\
(0.007)\end{array}$ & & \\
\hline Region Dummies & Yes & Yes & Yes & Yes & Yes \\
\hline Country of Birth Dummies & Yes & Yes & Yes & Yes & Yes \\
\hline Constant & $\begin{array}{r}0.331^{\star * *} \\
(0.091)\end{array}$ & $\begin{array}{r}-0.081^{* *} \\
(0.039)\end{array}$ & $\begin{array}{r}-0.310^{* * *} \\
(0.119)\end{array}$ & $\begin{array}{r}-0.111^{* *} \\
(0.045)\end{array}$ & $\begin{array}{r}0.046 \\
(0.063)\end{array}$ \\
\hline Observations & 23823 & 23823 & 23823 & 19939 & 10373 \\
\hline $\begin{array}{l}\text { This table reports first and second } \\
\text { married couples involving at least } \\
\text { old child residing in the household. } \\
\text { all families. Immigrants and their s } \\
\text { instrument is the percent foreign o } \\
\text { which he or she was most likely se } \\
\text { group clustering are reported in pa }\end{array}$ & $\begin{array}{l}\text { regression } \\
\text { preign-born } p \\
\text { sum of hush } \\
\text { s are betwe } \\
\text { opposite sex } \\
\text { ng for a spol } \\
\text { eses }\end{array}$ & $\begin{array}{l}\text { icients. Th } \\
t \text { with a bi } \\
\text { and wife's } \\
\text { e ages of } \\
\text { e immigra } \\
\text { Standard } € \\
* \star 0<0.05\end{array}$ & $\begin{array}{l}\text { sample c } \\
\text { ogical, nat } \\
\text { vages is } \mathrm{g} \\
5 \text { and } 64 . \\
\text { t's age gro } \\
\text { rors adjus }\end{array}$ & $\begin{array}{l}\text { onsists of in } \\
\text { ive-born } 16 \\
\text { reater is po } \\
\text { The exclud } \\
\text { up in the st } \\
\text { ed for state }\end{array}$ & $\begin{array}{l}\text { tact } \\
\text { or } 17 \text { year } \\
\text { siitve for } \\
\text { ed } \\
\text { ate in } \\
\text {-age }\end{array}$ \\
\hline
\end{tabular}

Table 3: First and Second Stage Estimates from IV Regressions 
First stage regression coefficients for this and the following robustness checks are not shown, but are virtually identical to the estimates in the first column of Table 3.

The interpretation of these results can be difficult if there is a difference between couples that come to the US already married and those that search for a spouse in the US. States with larger foreign born populations surely have more couples that come already married and so the instrument would not solve this type of problem. Ideally, the analysis would be conducted only on those immigrants that arrived unmarried, but the 2000 Census does not contain information on age at marriage. To mitigate concerns, I ran the regressions of interest on samples of immigrants that are very likely to have arrived single: First, in column 4, I drop all of those immigrant-immigrant couples that report arriving in the US in the same year. Second, in column 5, I include only those immigrants that arrived before the age 18. In the sample of couples arriving in different years, the coefficient on marriage to a native remains at around 0.12. However, the coefficient on marriage to a native is smaller and less precisely estimated using the sample of immigrants arriving as children. This is presumably due to a significantly smaller sample size coupled with the possibility that the children of young arrivers are slightly less sensitive to marriage decisions of their parents. In all specifications and samples, immigrants married to natives have children who are more likely to be high school dropouts.

As another robustness check not shown in the table, I conducted the analysis only on immigrants from English-speaking countries. ${ }^{15}$ Because immigrants from English-speaking countries share many cultural attributes with Americans and do not face language barriers, we can learn whether it is being a migrant that affects child outcomes or it is something related to language and the places from which immigrants migrate. The coefficients of interest were all insignificant when the sample was restricted to immigrants from English-speaking countries suggesting that the

\footnotetext{
${ }^{15}$ English-speaking countries are Canada, all of the countries in the United Kingdom, and Australia.
} 
benefits of immigrant-immigrant marriages arise from immigrants that are significantly different from the native born.

One limitation of the study is that its conclusions only apply to families that stay intact up until the child is 16 or 17 years old. The literature suggests that interethnic marriages are more likely to end in divorce (Kalmijn, de Graaf and Janssen 2005) and there is evidence that divorce has negative consequences on children's academic outcomes (for example, Pong 1997). This implies that it is even more beneficial for immigrants to marry other immigrants than what is suggested by the results in this paper. By comparing only intact mixed marriages to intact immigrantimmigrant marriages, we are not allowing for one of the mechanisms through which intermarriage could increase dropout rates. If marriages involving two immigrants are less likely to end in divorce than marriages involving a native and an immigrant, this could be one mechanism through which immigrant-immigrant marriages increase children's human capital.

\subsection{Gender Effects of Intermarriage}

Another interesting question is whether the effect of marriage to a native differs by gender of the immigrant. Ramakrishnan (2004) finds that conditional on race and age, second-generation immigrants with a native born father have lower dropout rates than those with native born mothers. Similarly, although it is unlikely that the difference is statistically significant, Chiswick and DebBurman (2003) find that children with a native father and foreign born mother have slightly higher levels of educational attainment than children with a foreign born father and native mother. Neither of these studies control for education of parents. However, there is evidence that the relationship between education and marriage to a US citizen differs by gender: Among married couples formed by a US citizen sponsoring an immigrant spouse, US citizen husbands and their wives have substantially more schooling than citizen wives and their husbands (Jasso and Rosenzweig 1990, 
Jasso et al. 2000). This section of the paper explores whether the effect of marriage to a native differs by gender of the foreign born parent when steps are taken to control for both observable and unobservable characteristics of immigrants and their spouses.

Table 4 presents regression results from specifications which allow for gender differences in the effects of marriage to a native. Just like in the previous sets of regressions, the immigrant residing in the US for the least amount of time is considered the person of interest in immigrant-immigrant couples, but results were robust to the different classification schemes discussed in footnote 10 . The first column shows regression results from a very basic least squares specification which includes an interaction between marriage to a native and being a foreign born male. The estimates suggest that while a foreign born female's marriage to a native decreases her child's probability of dropping out by almost one percentage point, a foreign born male's decision to marry a native has no effect on the probability that his child drops out of high school. This difference between males and females is statistically significant at the ten percent level. However, given the evidence provided by Jasso and Rosenzweig (1990) and Jasso et al. (2000) discussed above, one may suspect that the reason it is beneficial for immigrant females to marry natives is simply that these couples have more years of schooling on average.

To examine this issue, a richer set of controls is added to the model. The estimates in column 2 of Table 4 imply that a foreign born female's marriage to a native has no significant impact on her child's dropout probability, but a foreign born male's marriage to a native increases his child's dropout probability. Results from an F test of the sum of the coefficients on marriage to a native and its interaction with being male suggests that the effect of marriage to a native for a foreign born male is statistically significant at the five percent level.

There are many potential explanations for the seemingly different impacts of marriage to a native by gender. These findings are consistent with the large literature documenting that mother's 
characteristics are more influential than father's characteristics in determining child outcomes. If the foreign born are more optimistic than the native born (Kao and Tienda 1995) and what really matters for child human capital acquisition is the mother's optimism, then the only important factor should be whether a child's mother is foreign born. This implies that a foreign born male's decision to marry a foreign born female should decrease dropout rates of his children while a foreign born female's decision to marry a foreign born male should have no effect on dropout rates. Similar stories can be told if children are more likely to be bilingual or have positive ethnic role models if their mothers are foreign born.

To examine whether these gender differences reflect causal relationships, I turn to the instrumental variables strategy discussed in the previous subsection. The same instrument is used, but because there are two endogenous variables in this model, the second excluded instrument is simply the interaction between being male and the proportion foreign born of the never married opposite-sex population in the immigrant's age group and state. Column 3 of Table 4 shows the IV estimates. The coefficient on native born spouse becomes positive and significant for foreign born females. Although the effect for males is slightly larger in magnitude, the difference between males and females is not statistically significant. This suggests that the differential impact of marriage to a native by gender can be explained by unobservable characteristics of either the foreign born females that choose to marry natives or the native born males that choose to marry immigrant females. These unobservable characteristics may be ambition or optimism in the child's future. When the endogeneity of the intermarriage decision is taken into account, marriage to a native has roughly the same effect on dropout rates of children regardless of whether the immigrant is male or female. 


\begin{tabular}{|c|c|c|c|}
\hline Child Dropout & $\begin{array}{l}\text { OLS } \\
1 \\
\end{array}$ & $\begin{array}{l}\text { OLS } \\
2 \\
\end{array}$ & $\begin{array}{l}\text { IV } \\
3 \\
\end{array}$ \\
\hline Native Spouse & $\begin{array}{l}-0.008^{\star *} \\
(0.004)\end{array}$ & $\begin{array}{l}0.001 \\
(0.004)\end{array}$ & $\begin{array}{l}0.082^{\star \star \star} \\
(0.024)\end{array}$ \\
\hline Native Spouse x Male & $\begin{array}{l}0.008^{*} \\
(0.005)\end{array}$ & $\begin{array}{l}0.006 \\
(0.005)\end{array}$ & $\begin{array}{l}0.025 \\
(0.017)\end{array}$ \\
\hline Male & $\begin{array}{l}-0.000 \\
(0.003)\end{array}$ & $\begin{array}{l}-0.001 \\
(0.003)\end{array}$ & $\begin{array}{l}0.001 \\
(0.007)\end{array}$ \\
\hline Child's Age & $\begin{array}{l}0.007^{\star * *} \\
(0.002)\end{array}$ & $\begin{array}{l}0.007^{\star * *} \\
(0.002)\end{array}$ & $\begin{array}{l}0.008^{\star * *} \\
(0.002)\end{array}$ \\
\hline Female Child & $\begin{array}{l}-0.008^{\star * *} \\
(0.002)\end{array}$ & $\begin{array}{l}-0.008^{\star * *} \\
(0.002)\end{array}$ & $\begin{array}{l}-0.008^{* * *} \\
(0.002)\end{array}$ \\
\hline Metropolitan Area & $\begin{array}{l}-0.000 \\
(0.005)\end{array}$ & $\begin{array}{l}0.004 \\
(0.005)\end{array}$ & $\begin{array}{l}0.013^{\star \star} \\
(0.006)\end{array}$ \\
\hline Years of Schooling & & $\begin{array}{l}-0.001^{* * *} \\
(0.000)\end{array}$ & $\begin{array}{l}-0.001^{*} \\
(0.000)\end{array}$ \\
\hline Spouse Years of Schooling & & $\begin{array}{l}-0.001^{\star \star \star} \\
(0.000)\end{array}$ & $\begin{array}{l}-0.003^{\star \star \star} \\
(0.001)\end{array}$ \\
\hline Log Couple's Wage Income & & $\begin{array}{l}-0.002 \\
(0.001)\end{array}$ & $\begin{array}{l}-0.003^{*} \\
(0.002)\end{array}$ \\
\hline Working Mother & & $\begin{array}{l}0.001 \\
(0.003)\end{array}$ & $\begin{array}{l}-0.002 \\
(0.002)\end{array}$ \\
\hline Number of Children in Household & & $\begin{array}{l}0.002^{*} \\
(0.001)\end{array}$ & $\begin{array}{l}0.003^{\star *} \\
(0.001)\end{array}$ \\
\hline Maximum Years in US & & $\begin{array}{l}-0.000^{*} \\
(0.000)\end{array}$ & $\begin{array}{l}-0.001^{\star \star *} \\
(0.000)\end{array}$ \\
\hline Does Not Speak English & & $\begin{array}{l}0.034^{\star \star \star} \\
(0.012)\end{array}$ & $\begin{array}{l}0.035^{\star \star} \\
(0.015)\end{array}$ \\
\hline Spouse Does Not Speak English & & $\begin{array}{l}0.001 \\
(0.008)\end{array}$ & $\begin{array}{l}0.016^{*} \\
(0.010)\end{array}$ \\
\hline State Percent Foreign Born & & $\begin{array}{l}-0.031^{\star} \\
(0.019)\end{array}$ & $\begin{array}{l}0.038^{*} \\
(0.023)\end{array}$ \\
\hline Region Dummies & Yes & Yes & Yes \\
\hline Country of Birth Dummies & No & Yes & Yes \\
\hline Constant & $\begin{array}{l}-0.087^{\star *} \\
(0.034)\end{array}$ & $\begin{array}{l}-0.041 \\
(0.039)\end{array}$ & $\begin{array}{l}-0.068^{*} \\
(0.036)\end{array}$ \\
\hline Observations & 23823 & 23823 & 23823 \\
\hline \multicolumn{4}{|c|}{$\begin{array}{l}\text { This table reports regression coefficients from least squares and IV } \\
\text { models. The sample consists of intact married couples involving at } \\
\text { least one foreign-born parent with a biological, native-born } 16 \text { or } 17 \\
\text { year old child residing in the household. The sum of husband and } \\
\text { wife's wages is greater is posiitve for all families. Immigrants and their } \\
\text { spouses are between the ages of } 35 \text { and } 64 \text {. Standard errors in the IV } \\
\text { specification are adjusted for state-age group clustering. }{ }^{* \star *} p<0.01 \text {, }{ }^{* *} \\
p<0.05,{ }^{*} p<0.10 \text {. }\end{array}$} \\
\hline
\end{tabular}

Table 4: Gender Effects of Marriage to a Native 


\section{Conclusions}

This paper attempts to shed some light on the relationship between immigrants' marital assimilation and their children's academic success by examining the role of intermarriage in determining children's dropout rates. Previous literature suggests that an immigrant's marriage to a native improves children's academic outcomes, but the literature typically does not consider the fact that immigrants that marry natives have other characteristics which may affect child outcomes.

This paper finds that although second-generation immigrants with one native parent generally have lower dropout rates than those with two foreign born parents, the relationship reverses when controls such as education and income are added to the model. The positive effect of marriage to a native on dropout probabilities of children increases slightly when controls for assimilation and country of birth fixed effects are added to the model. Instrumental variables estimates also suggest that immigrants that marry natives have children that are more likely to dropout of high school than immigrants that marry other immigrants. It was also found that gender differences in the effect of marriage to a native disappear in specifications which control for the endogeneity of the marriage decision.

These results can be interpreted as evidence that immigrants' association with natives is not unambiguously beneficial for assimilation. This is consistent with many newer theories of assimilation which, contrary to traditional "straight line assimilation" theories, posit that the ways in which immigrants assimilate depend on their specific family and community circumstances (Alba and Nee 2003). Perreira et al. (2006) find that Hispanic, Asian, and African immigrants that arrive in the US as children obtain more education than their parents, but that the second and higher generations do not do as well. They interpret this with a model in which cultural capital and immigrant optimism protect the young from the unfavorable community and school environments to which immigrants are typically exposed. 
Countries often explicitly place refugees in specific parts of the country specifically to hasten the speed of assimilation. Denmark recently enacted a policy which restricts the ability of immigrants to import spouses from their home countries. These types of policies may lead to more assimilation in some aspects such as language acquisition and earnings mobility. However, this paper suggests that marriage to a native, one measure of social integration, actually increases children's dropout rates when steps are taken to control for the characteristics, observable and unobservable, of the parents that choose to intermarry. This implies that resources should be spent on improving the community and school environments of immigrants and their children as opposed to spending resources trying to integrate immigrants into predominantly native communities. One caveat, however, is that this paper only considers one academic outcome of children. It may be that while native parents increase the probability that children drop out of high school, they may also increase the probability that children graduate from college. Examining the effects of intermarriage on other measures of child success remains an area ripe for future research.

\section{References}

[1] Alba, Richard and Victor Nee. Remaking the American Mainstream: Assimilation and Contemporary Immigration. Cambridge, MA: Harvard University Press, (2003).

[2] Baker, Michael and Dwayne Benjamin. "The Role of the Family in Immigrants' Labor Market Activity: An Evaluation of Alternative Explanations." American Economic Review. Vol. 87, (1997), 705-727.

[3] Bean, Frank and Gillian Stevens. America's Newcomers and the Dynamics of Diversity. New York: Russell Sage Foundation. (2003). 
[4] Blau, Francine, Lawrence M. Kahn, Joan Moriarty, and Andre Souza. "The Role of the Family in Immigrants' Labor-Market Activity: An Evaluation of Alternative Explanations: Comment," American Economic Review. Vol. 93, Issue 1, (2003), 429-447.

[5] Bleakley, Hoyt and Aimee Chin. "What Holds Back the Second Generation? The Intergenerational Transmission of Language Human Capital Among Immigrants." Journal of Human Resources, Vol. 43, (2008), 267-298.

[6] Card, David. "Is the New Immigration Really so Bad?" Economic Journal. Vol. 115, Issue 507, (2005), F300-F323.

[7] Chiswick, Barry. "Sons of Immigrants: Are They at an Earnings Disadvantage?" American Economic Review, (1977), 376-380.

[8] Celikaksoy, Aycan, Helena Skyt Nielson, and Mette Verner. "Marriage Migration: Just Another Case of Positive Assortative Matching?" Review of Economics of the Household. Vol. 4, (2006), $253-275$

[9] Chiswick, Barry and Noyna DebBurman. "Educational Attainment: Analysis by Immigrant Generation." Economics of Education Review, Vol. 23, Issue 4, (2004), 361-379.

[10] Duncan, Brian and Stephen Trejo. "Intermarriage and the Intergenerational Transmission of Ethnic Identity and Human Capital for Mexican Americans." IZA Discussion Paper 3547, (2008).

[11] Edin, Per-Anders, Peter Fredriksson, and Olof Aslund. "Ethnic Enclaves and the Economic Success of Immigrants-Evidence from a Natural Experiment." Quarterly Journal of Economics. Vol.118, Issue 1, (2003), 329-57. 
[12] Farley, Reynolds. "The New Census Question about Ancestry: What Did It Tell Us?" Demography. Vol. 28, Issue 3, (1991), 411- 429.

[13] Furtado, Delia. "Human Capital and Interethnic Marriage Decisions." IZA Discussion Paper 1989, (2006).

[14] Gang, Ira and Klaus Zimmerman. "Is Child like Parent? Educational Attainment and Ethnic Origin." Journal of Human Resources. Issue 35, (2000), 550-569.

[15] Glick, Jennifer and Michael White. "The Academic Trajectories of Immigrant Youths: Analysis Within and Across Cohorts." Demography. Vol 40, Issue 4, (2003), 759-783.

[16] Grieco E. M. and Cassidy R. C. "Overview of Race and Hispanic Origin." Census 2000 Brief series. U.S. Census Bureau, March. (2001).

[17] Jasso, Guillermina and Mark Rosenzweig. The New Chosen People : Immigrants in the United States. New York : Russell Sage Foundation. (1990).

[18] Jasso, Guillermina, Douglas Massey, Mark Rosenzweig, and James Smith. "Assortative Mating Among Married New Legal Immigrants to the United States: Evidence From the New Immigrant Survey Pilot, " International Migration Review. Vol 34, Issue 2, (2000), 443-459.

[19] Kalmijn, Matthijs. "The Socioeconomic Assimilation of Caribbean American Blacks." Social Forces, Vol 74, Issue 3, (1996), 911-930.

[20] Kalmijn, Matthijs, Paul M. de Graaf and Jacques P. G. Janssen. "Intermarriage and the Risk of Divorce in the Netherlands: The Effects of Differences in Religion and in Nationality." Population Studies. Vol. 59, Issue 1, (2005), 71-85.

[21] Kantarevic, Jasmin. "Interethnic Marriages and Economic Assimilation of Immigrants." IZA Discussion Paper, No. 1142. 
[22] Kao, Grace. and Marta Tienda. "Optimism and Achievement: The Educational Performance of Immigrant Youth.” Social Science Quarterly. Vol. 76, (1995), 1-19.

[23] Larsen, Luke. "The Foreign Born Population in the United States: 2003.” Current Population Reports. Population Characteristics. Series P20-551, (2004).

[24] Meng, Xin and Robert G. Gregory. "Intermarriage and the Economic Assimilation of Immigrants." Journal of Labor Economics. Vol. 23, Issue 1, (2005), 135-75.

[25] Meng, Xin and Dominique Meurs. "Intermarriage, Language, and Economic Assimilation Process: A Case Study of France." IZA Discussion Paper, No. 2461 (2006).

[26] Merton, Robert K. "Intermarriage and the Social Structure: Fact and Theory." Psychiatry Vol 4, (1941).

[27] Murnane, Richard, John Willett, and John Tyler, 2000. "Who Benefits from Obtaining a GED? Evidence from High School and Beyond." The Review of Economics and Statistics. Vol. 82, Issue 1, (2000), 23-37.

[28] Munshi, Kaivan : "Networks in the Modern Economy: Mexican Migrants in the US Labor Market." Quarterly Journal of Economics. Vol. 118, Issue 2, (2003), 549-597.

[29] Nielson, Helena Skyt, Nina Smith, and Aycan Celikaksoy. "The Effect of Marriage on Education of Immigrants: Evidence from a Policy Reform Restricting Spouse Import." IZA Discussion Paper, No. 2899 (2007).

[30] Perreira, Krista, Kathleen Mullan Harris, and Dohoon Lee. "Making it in America: High School Completion By Immigrant and Native Youth." Demography. Vol. 43, Issue 3, (2006), 511-536. 
[31] Pong, Suet-Ling. "Family Structure, School Context, and Eighth-Grade Math and Reading Achievement." Journal of Marriage and the Family. Vol. 59, Issue 3, (1997), 734-746.

[32] Portes, Alejandro and Min Zhou. "The New Second Generation: Segmented Assimilation and its Variants Among Post-1965 Immigrant Youth." Anals of the American Academy of Political and Social Sciences, Vol. 530, (1993), 74-96.

[33] Qian, Zhenchao and Daniel Lichter. "Measuring Marital Assimilation: Intermarriage among Natives and Immigrants." Social Science Research, Vol. 30, (2001), 289-312.

[34] Ramakrishnan, S. Karthick. "Second-Generation Immigrants? The '2.5 Generation' in the United States." Social Science Quarterly, Vol 85, Issue 2, (2004), 380-399.

[35] Ruggles, Steven and Matthew Sobek et al. Integrated Public Use Microdata Series: Version 3.0 Minneapolis: Historical Census Projects, University of Minnesota, 2003.

[36] Stevens, Gillian and Gray Swicegood. "The Linguistic Context of Ethnic Endogamy." American Sociological Review. Vol 52, Issue 1, (1987), 73-82.

[37] van Ours, Jan C. and Veenman, Justus. "How Interethnic Marriages Affect the Educational Attainment of Children: Evidence from a Natural Experiment." CentER Discussion Paper No. 2008-07 Available at SSRN: http://ssrn.com/abstract=1092417 (2008). 